\title{
Evaluation of a New Acid Solution for Texturization of Multicrystalline Silicon Solar Cells
}

\author{
Ryosuke Watanabe, ${ }^{1}$ Shuuji Abe, ${ }^{1,2}$ Satoshi Haruyama, ${ }^{1}$ Tatsunobu Suzuki, ${ }^{2}$ \\ Mitsuo Onuma, ${ }^{2}$ and Yoji Saito ${ }^{1}$ \\ ${ }^{1}$ Department of Systems Design Engineering, Seikei University, 3-3-1 Kichijoji-Kitamachi, Musashino, Tokyo 180-8633, Japan \\ ${ }^{2}$ Nippon Kasei Chemical Co., Ltd., Onahama, Iwaki, Fukushima 971-8101, Japan
}

Correspondence should be addressed to Ryosuke Watanabe; rwatanabe@st.seikei.ac.jp

Received 24 July 2013; Accepted 11 September 2013

Academic Editor: Minjoong Yoon

Copyright (C) 2013 Ryosuke Watanabe et al. This is an open access article distributed under the Creative Commons Attribution License, which permits unrestricted use, distribution, and reproduction in any medium, provided the original work is properly cited.

\begin{abstract}
Surface texturing methods using an alkaline solution for monocrystalline $\mathrm{Si}$ (c-Si) solar cells have been widely accepted to improve cell performance. However, multicrystalline $\mathrm{Si}(\mathrm{mc}-\mathrm{Si})$ cells are difficult to be texturized by alkaline etching, because the grains in the substrates are randomly oriented. In this study, we considered a $\mathrm{HF} / \mathrm{HNO}_{3} / \mathrm{H}_{2} \mathrm{SO}_{4}$ acid solution for texturing the mc-Si cells. We evaluated the morphology of the textured surfaces and the reflectance spectra from the surfaces. The deep dimple textured structures are formed on the surfaces for only 30 seconds of the acid texturing process. This behavior results from the effect of $\mathrm{H}_{2} \mathrm{SO}_{4}$ in the solution. This process obtains up to $14.7 \%$ conversion efficiencies of the acid textured cells. These conversion efficiencies are up to 1.3 times larger than those of the mirror-etched cells.
\end{abstract}

\section{Introduction}

Bulk silicon-based solar cells are considered as a first choice for mass production and constituted more than $80 \%$ of total shipments in 2010 [1]. Specifically, the share of multicrystalline silicon (mc-Si) solar cells is still above $40 \%$ due to the possibility of lower manufacturing cost than monocrystalline silicon (c-Si) solar cells.

Surface texturing for Si solar cells is a key technology for improving cell efficiency and is beneficial for low-cost cells. A surface texturing method can reduce light reflectance on the surface of the cells quite efficiently and achieve more adequate light absorption enhancement inside the cells than the absorption of the flat surface cells $[2,3]$.

A low cost surface texturing method by wet etching using an alkaline solution is widely accepted for improving short circuit current of the c-Si cells. This method uses dependence of the etch rate on crystalline orientation of silicon. Random pyramid structures with a few micron orders can be formed by the alkaline wet etching process.
In contrast to c-Si cells, surface texturing methods for mass production of $\mathrm{mc}$-Si cells have not been well established. Alkaline texturing is not effective for $\mathrm{mc}-\mathrm{Si}$ cells, because the grains in mc-Si wafers are randomly oriented. Various alternative methods for texturing the surface of mc-Si cells have been explored [4-7]; however, these methods also have several problems for practical use. For example, reactive ion etching (RIE) [7] is one of the candidates for texturing mcSi cells and can enhance cell efficiency sufficiently. However, after the RIE etching process, an additional post process is needed to remove the damaged surface layers, and this will increase the cost of production. Other methods, for instance, mechanical etching $[4,5]$ and/or laser etching [6], have also been suggested. However, these methods are difficult to use practically because of cost and/or productivity issues.

Acidic texturing methods using $\mathrm{HF} / \mathrm{HNO}_{3}$ solutions with an additional diluent like $\mathrm{CH}_{3} \mathrm{COOH}$ are currently being developed for texturing mc-Si cells [8-11]. Although the surfaces of the cells textured by an acid solution have relatively high reflectance compared with those of RIE textured cells 


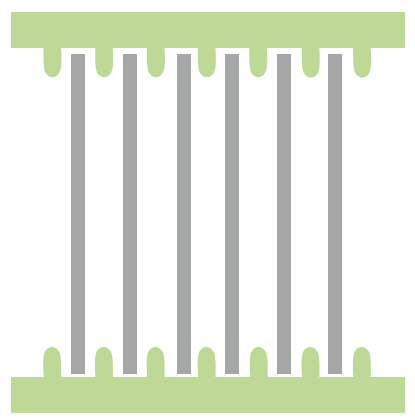

Sample setting

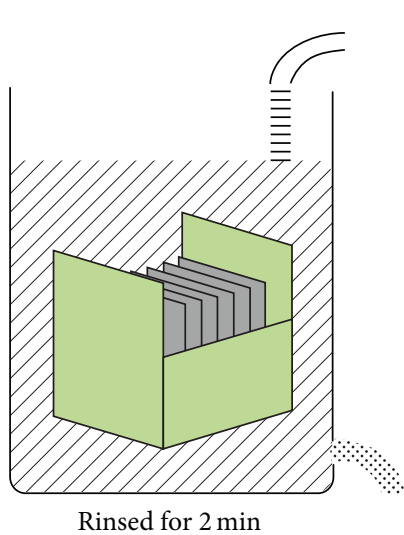

Rinsed for $2 \mathrm{~min}$

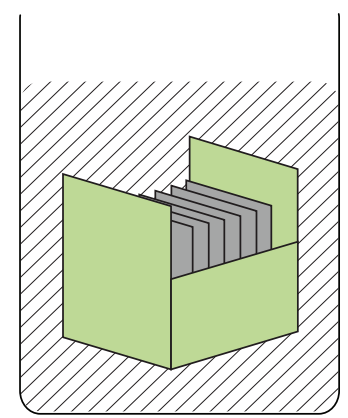

Etching
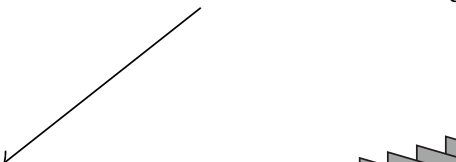

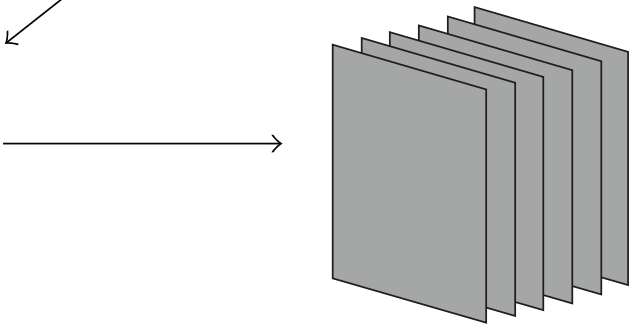

Drying

FIGURE 1: Schematic diagrams for acid texturing procedure.

[11], the acidic texturing method is a candidate for a mass production due to its low cost.

In our study, we consider an alternative diluent instead of $\mathrm{CH}_{3} \mathrm{COOH}$ to realize a more suitable acidic texturing method. We used a $\mathrm{HF} / \mathrm{HNO}_{3}$ solution with $\mathrm{H}_{2} \mathrm{SO}_{4}$ instead of a $\mathrm{HF} / \mathrm{HNO}_{3}$ solution with $\mathrm{CH}_{3} \mathrm{COOH}$. A HF/ $\mathrm{HNO}_{3} / \mathrm{H}_{2} \mathrm{SO}_{4}$ system for surface texturing has previously been reported [12-15]; however, cell performance has never been investigated. As far as we know, this paper is the first to consider the cell performance of the acid textured cells using the $\mathrm{HF} / \mathrm{HNO}_{3} / \mathrm{H}_{2} \mathrm{SO}_{4}$ system. In this report, we demonstrate comparable conversion efficiency up to $14.7 \%$ by using the wet etching process for only 30 seconds. The acid texturing method using a $\mathrm{HF} / \mathrm{HNO}_{3} / \mathrm{H}_{2} \mathrm{SO}_{4}$ solution with sufficiently short etching time is preferable for mass production.

\section{Experimental Procedure}

2.1. Surface Texturing. In this experiment, $156 \times 156 \mathrm{~mm}$ ascut p-type boron-doped multi-crystalline Si substrates with $190 \pm 20 \mu \mathrm{m}$ thicknesses were used. Resistivity of the wafers was from 0.5 to $2 \Omega \mathrm{cm}$. The texturing procedure in Figure 1 was as follows. After the wafers were cleaned by deionized water (DIW), the acidic texturing for the wafers was carried out using $24 \mathrm{~kg}$ of $\mathrm{HF} / \mathrm{HNO}_{3} / \mathrm{H}_{2} \mathrm{SO}_{4}$ solutions. The volume ratio of the solution used in this experiment was mainly $\mathrm{HF}: \mathrm{HNO}_{3}: \mathrm{H}_{2} \mathrm{SO}_{4}=1: 1.6: 8.2$. In each etching experiment, six wafers were simultaneously etched. The temperature of the solution was fixed at $17^{\circ} \mathrm{C}$ for each experiment. Etching time was changed from 30 to 60 seconds. Typical etched depth was about $5 \mu \mathrm{m}$ for 60 seconds. Then the wafers were rinsed with DIW for 2 minutes followed by drying. After acidic texturing of the wafers, the etched surfaces were observed with scanning electron microscopy (SEM). Optical reflection measurements were performed using a double beam spectrometer with an integrating sphere. An angle spacer was also used to prevent specular reflection.

After the texturing process, we fabricated mc-Si solar cells using a conventional method [16]. The cell fabrication procedure is summarized in Figure 2. First, the substrates were cut to $20 \times 30 \mathrm{~mm}^{2}$ pieces and then chemically cleaned with a hot alkaline solution $\left(\mathrm{NH}_{4} \mathrm{OH}: \mathrm{H}_{2} \mathrm{O}_{2}: \mathrm{H}_{2} \mathrm{O}=1: 1: 6\right)$. The substrates were rinsed with DIW, dipped into a diluted HF solution, and rinsed again with DIW. To form a $\mathrm{p}-\mathrm{n}$ junction, phosphorus was doped by thermal diffusion to the textured substrates at $940^{\circ} \mathrm{C}$ for 40 minutes. The spin-on diffusion source T-1 P59320 (Tokyo Ohka Kogyo Co. Ltd.) was used as a phosphorus source to form doped oxide films onto the substrates during the diffusion process. After the diffusion process, the diffused layers of the rear side and near the edge were removed by etching using an acid solution $\left(\mathrm{HF}: \mathrm{HNO}_{3}: \mathrm{CH}_{3} \mathrm{COOH}=2: 3: 6\right)$. The area of the measured diffused layer was $4.32 \mathrm{~cm}^{2}$. Then, aluminum films were evaporated and patterned to form the front and rear electrodes, and the substrates were sintered at $450^{\circ} \mathrm{C}$ in nitrogen ambient. After cell fabrication, the electrical characteristics of 
TABLE 1: Electrical parameters of the acid textured and the mirror-etched cells.

\begin{tabular}{|c|c|c|c|c|c|c|c|c|c|}
\hline & $\begin{array}{l}\text { Etching time } \\
\quad(\mathrm{sec})\end{array}$ & $V_{\mathrm{oc}}(\mathrm{mV})$ & $J_{\mathrm{sc}}\left(\mathrm{mA} / \mathrm{cm}^{2}\right)$ & Fill factor & Efficiency (\%) & $\begin{array}{c}\text { Absorption } \\
(\%, \text { at } \\
600 \mathrm{~nm})\end{array}$ & Normalized $J_{\mathrm{sc}}$ & $\begin{array}{l}\text { Normalized } \\
\text { efficiency }\end{array}$ & $\begin{array}{c}\text { Normalized } \\
\text { absorption }\end{array}$ \\
\hline \multirow{3}{*}{ Textured } & 30 & 564 & 34.1 & 0.76 & 14.7 & 81.1 & 1.30 & 1.32 & 1.35 \\
\hline & 45 & 558 & 32.2 & 0.77 & 13.8 & 78.0 & 1.22 & 1.24 & 1.30 \\
\hline & 60 & 577 & 30.6 & 0.77 & 13.6 & 76.7 & 1.16 & 1.23 & 1.27 \\
\hline Mirror & & 563 & 26.3 & 0.75 & 11.1 & 60.2 & 1 & 1 & 1 \\
\hline
\end{tabular}

the fabricated solar cells were investigated at $25^{\circ} \mathrm{C}$ under the illumination of AM1.5 using a solar-simulated light source (type XC-500EFSS, Seric Ltd.). The solar-simulated light source has a spectral distribution according to the class A of JIS C-8912, between 400 and $1100 \mathrm{~nm}$. Power density of the illumination was calibrated using a solar power meter (type ANS-001, San-ei Electric Co.) for a solar simulator. Note that in this study we focus on the properties of texturing, thus we mainly fabricated the cells without antireflection coating (ARC) to prevent ambiguity.

\section{Results and Discussion}

3.1. Morphology of the Textured Surface. First, we investigated time dependence of surface morphology of the wafers by acid texturing using SEM. The cleaned mc-Si substrates were dipped into the acid solution ( $\mathrm{HF}: \mathrm{HNO}_{3}: \mathrm{H}_{2} \mathrm{SO}_{4}=$ $1: 1.6: 8.2$ ) for 30,45 , and 60 seconds, respectively. Figure 3 shows the SEM images of the textured surfaces for each etching time condition. The figures show that the textured structure is a few micrometers. Note that in this experiment sufficient textured structures can be obtained in shorter etching times (30 to 60 seconds) than those in previous reports (a few minutes).

Figures 3(d)-3(f) show cross-sectional images of the textured surfaces. These figures indicate that deep dimple textured structures are generated on the surface of the substrates. Aspect ratio of the textured structure decreases as the etching time increases. These behaviors agree with those in previous research [8]. According to Nishimoto et al. [8], at an initial stage textured structures are formed by preferential etching of the damaged region, such as the cracks formed during wafer sawing. However, excess etching will result in smoothing the surfaces.

Next, we investigated the difference in the morphology between conventional acidic textured surfaces $\left(\mathrm{HF} / \mathrm{HNO}_{3} /\right.$ $\mathrm{CH}_{3} \mathrm{COOH}$ solution) and the textured surfaces using a $\mathrm{HF} / \mathrm{HNO}_{3} / \mathrm{H}_{2} \mathrm{SO}_{4}$ solution. Figure 4 shows an example of the morphology of the acidic textured cells using a $\mathrm{HF} / \mathrm{HNO}_{3} / \mathrm{CH}_{3} \mathrm{COOH}$ solution. Figure 4 indicates that semispherical structures are formed on the surface. It is considered that generated gas bubbles consist of $\mathrm{NO}_{2}$ while texturing leads to semispherical structures on the surface [8].

In the case of $\mathrm{HF} / \mathrm{HNO}_{3} / \mathrm{H}_{2} \mathrm{SO}_{4}$ acid solution, the texturing shape is slightly roughened and worm-eaten. It has been reported that the $\mathrm{H}_{2} \mathrm{SO}_{4}$ in the solution stabilizes the intermediary formed nitrogen containing species (e.g.,
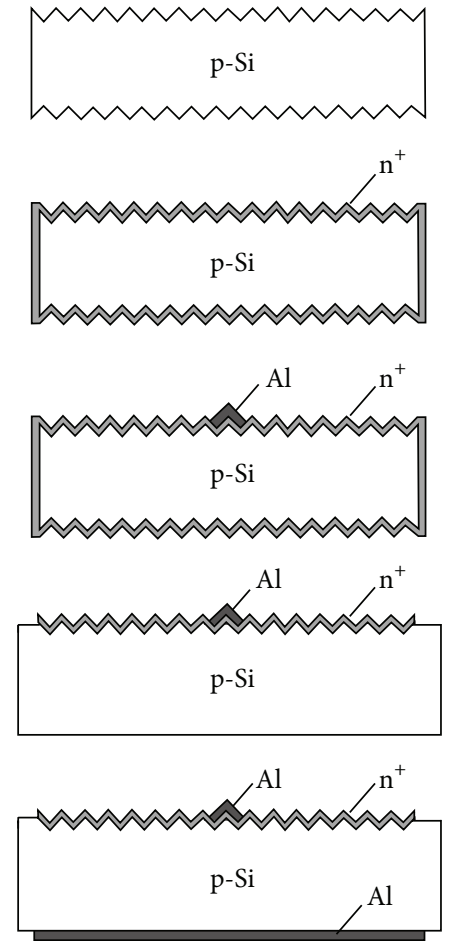

FIGURE 2: Schematic diagrams for solar cell fabrication process.

$\mathrm{NO}_{2}{ }^{-}, \mathrm{NO}^{+}$, etc.) that are responsible for the silicon etching process, and this enhances the etching reaction [13-15]. Also, high viscosity of the $\mathrm{H}_{2} \mathrm{SO}_{4}$ can prevent convection of these species and enhance the localized reaction. We expected that the localized enhancement of etching would maintain the textured structures.

3.2. Reflectance Measurements. We investigated the etching time dependence of the reflectance of the acid textured surfaces. Figure 5 shows the reflectance spectra of the textured surfaces that were etched with a $\mathrm{HF} / \mathrm{HNO}_{3} / \mathrm{H}_{2} \mathrm{SO}_{4}$ solution for 30 to 60 seconds. In this experiment, we also fabricated a sample etched for 30 seconds and covered by an ARC, where the ARC was deposited by an RF magnetron sputtering method using a $\mathrm{Si}_{3} \mathrm{~N}_{4}$ target. Evaluated refractive index of the ARC was 1.7 at a wavelength of $600 \mathrm{~nm}$, and the value is slightly lower because of unexpected oxidization during the deposition. In addition, the reflectance spectrum of the mirror-etched sample is also shown as a reference in Figure 5. 


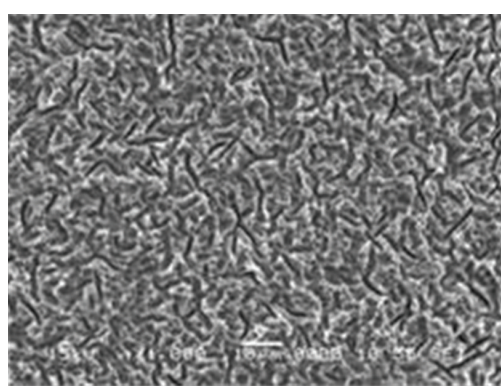

(a)

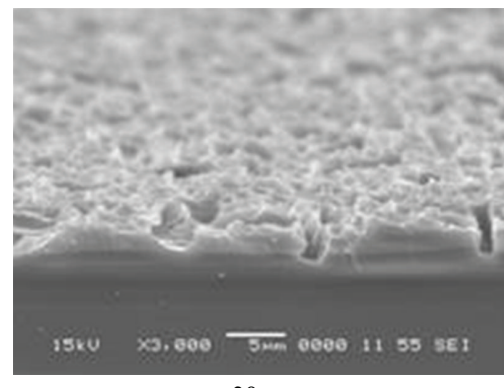

$30 \mathrm{~s}$

(d)

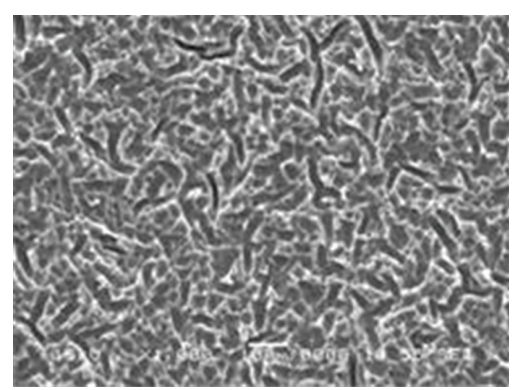

(b)

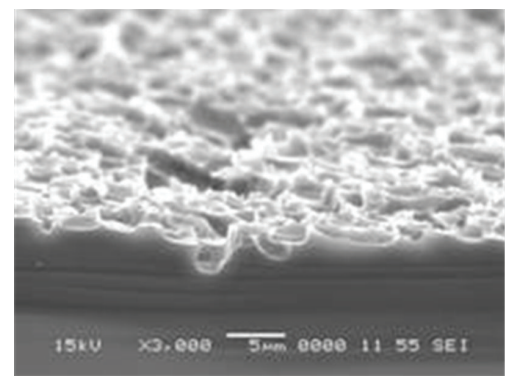

$45 \mathrm{~s}$

(e)

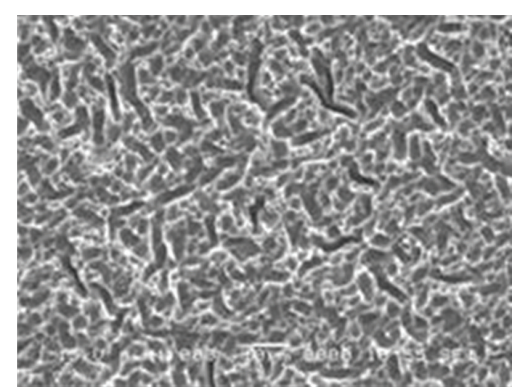

(c)

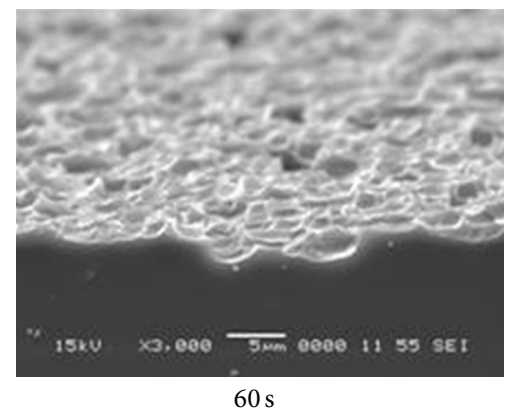

(f)

Figure 3: SEM images of acid textured surfaces using $\mathrm{H}_{2} \mathrm{SO}_{4}$ diluent. ((a)-(c)) Top view. ((d)-(f)) Cross-sectional view. (a), (d) 30 sec, (b), (e) $45 \mathrm{sec}$, and (c), (f) $60 \mathrm{sec}$ of etching.

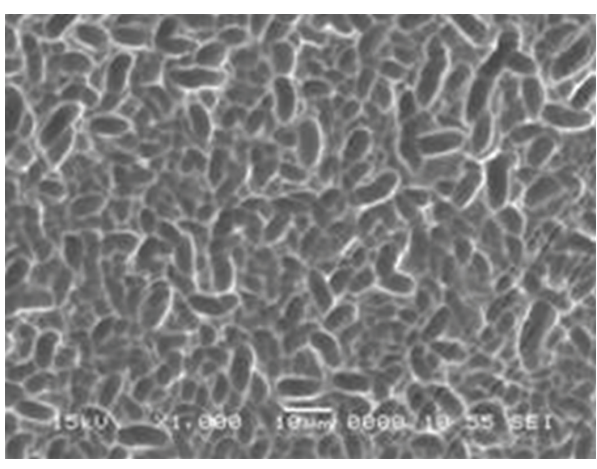

(a)

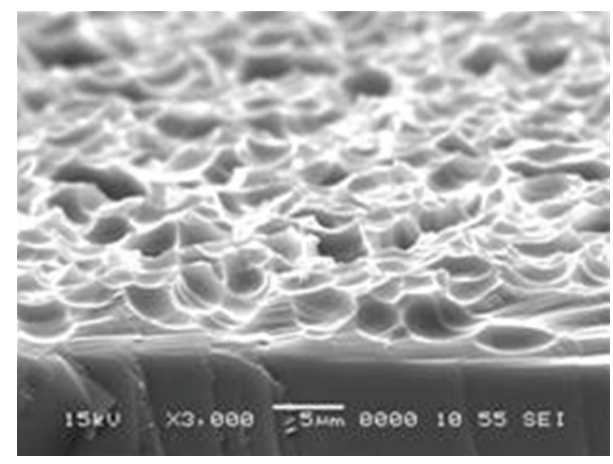

(b)

FIgurE 4: Typical SEM images of acid textured surfaces using $\mathrm{CH}_{3} \mathrm{COOH}$ diluent. (a) Top view. (b) Cross-sectional view.

Figure 5 indicates that the reflectance of the textured surface increases as the etching time increases. These behaviors correspond to the surface morphology of the substrate as mentioned before. For longer etching times, the textured surface is smoothed and the aspect ratio of the texturing is decreased. In our experiment, 30 -second acid etching is preferable for maintaining the texturing effect and suppressing light reflection from the surface of the wafers. Thus, reflection is effectively reduced after only 30 seconds of etching using the $\mathrm{HF} / \mathrm{HNO}_{3} / \mathrm{H}_{2} \mathrm{SO}_{4}$ acidic solution.

Figure 5 also indicates the reflectance of the textured surface with the ARC. This shows that low reflection below $5 \%$ is achieved at a wavelength of $600 \mathrm{~nm}$.
3.3. Cell Characterization. Table 1 lists the electrical parameters of the acid textured mc-Si cells under the illumination of AM1.5. The parameters of the mirror surface cell are also shown as a reference in Table 1 . The right side of Table 1 also indicates normalized values of $J_{\mathrm{sc}}$, conversion efficiency, and absorption $(\lambda=600 \mathrm{~nm}$, rest of the reflected light) of the textured cells with respect to those of the mirror cell. The table clearly shows that the cell textured for 30 seconds has the highest efficiency. Also the textured cell etched for 30 seconds shows a relatively high $J_{\mathrm{sc}}$ value compared with other samples. Sufficient light confinement in the textured cells results in low reflectance and $J_{\text {sc }}$ enhancement. Table 1 also shows that the increases in the $J_{\mathrm{sc}}$ and the conversion 


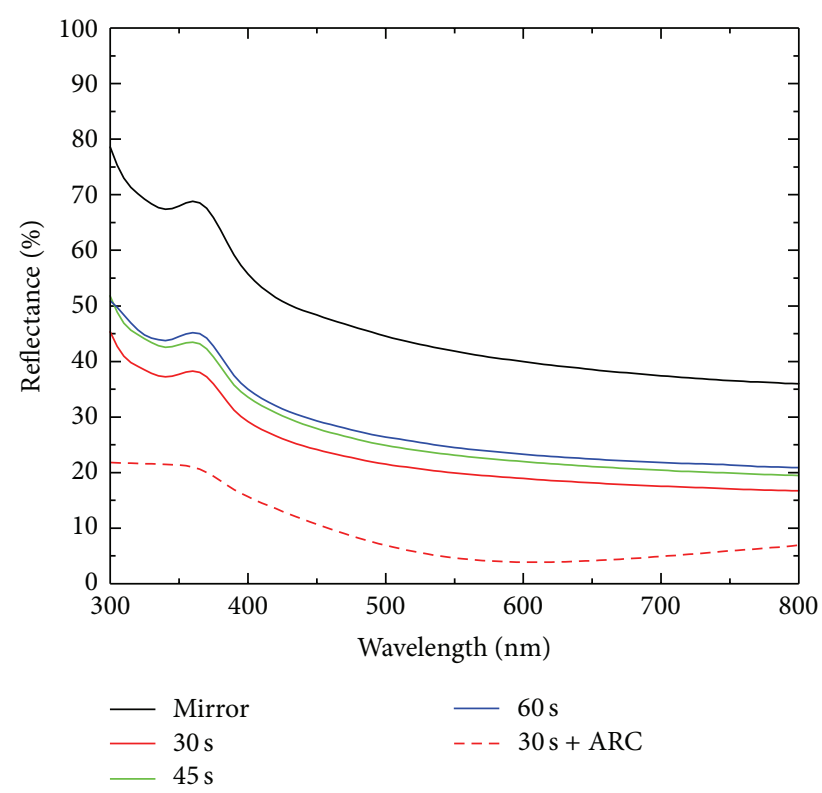

FIGURE 5: Reflectance spectra from the acid textured surface using $\mathrm{H}_{2} \mathrm{SO}_{4}$ diluent. Etching times are 30, 45, and 60 seconds. Dotted line: reflection from 30-second etched surface with ARC.

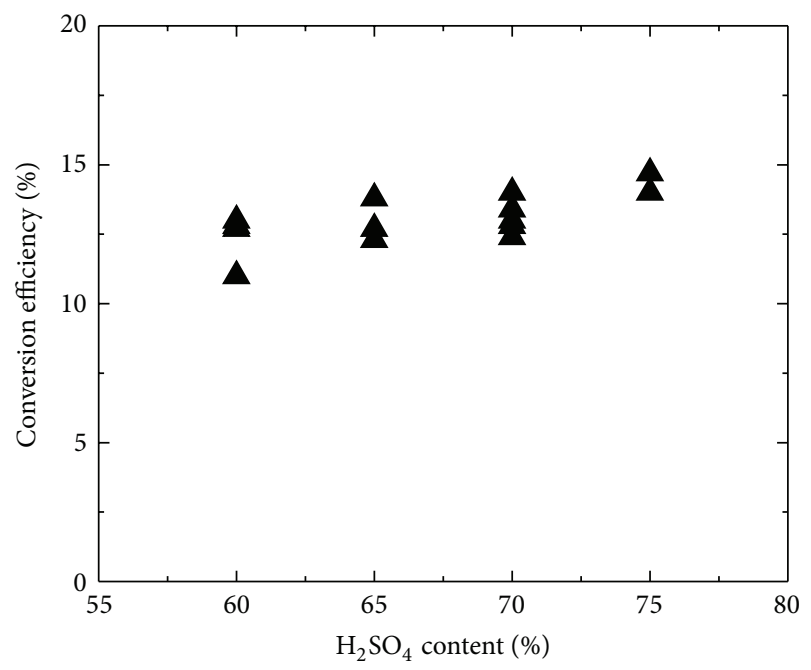

FIGURE 6: Conversion efficiencies of cells versus $\mathrm{H}_{2} \mathrm{SO}_{4}$ content in acid solution.

efficiency of the cells are consistent with the increase in light absorption in the cells. This indicates that the acid etching process using $\mathrm{HF} / \mathrm{HNO}_{3} / \mathrm{H}_{2} \mathrm{SO}_{4}$ solution barely affects the fill factor or surface recombination losses and only enhances cell absorption.

3.4. Solar Cell Fabrication. We also fabricated the textured cells with the ARC. The cells with the ARC show enhanced conversion efficiency of $1 \%$ to $2 \%$ higher than that of the cells without ARC.
Figure 6 shows the conversion efficiencies of the cells versus the $\mathrm{H}_{2} \mathrm{SO}_{4}$ content in the acidic solution. In our study, the $\mathrm{H}_{2} \mathrm{SO}_{4}$ content was changed from $60 \%$ to $75 \%$. The figure indicates that the conversion efficiencies slightly increase as the ratio of $\mathrm{H}_{2} \mathrm{SO}_{4}$ increases. When the content of $\mathrm{H}_{2} \mathrm{SO}_{4}$ is $75 \%$, maximum conversion efficiency is achieved.

In our experiments, the mc-Si cell, which was textured by the $\mathrm{HF} / \mathrm{HNO}_{3} / \mathrm{H}_{2} \mathrm{SO}_{4}$ acid solution for 30 seconds, achieved a conversion efficiency of up to $14.7 \%$ and fill factor of 0.76 . The cells textured by $\mathrm{HF} / \mathrm{HNO}_{3} / \mathrm{H}_{2} \mathrm{SO}_{4}$ solution can achieve properties comparable with those of acid textured mc-Si cells using other diluents reported by other researches [810]. Specifically, Nishimoto et al. [8], Kim et al. [9], and Gangopadhyay et al. [10] reported conversion efficiencies ranging from 11.51 to $14.94 \%$ and fill factors from 0.692 to 0.77 . Therefore, the cell textured by the $\mathrm{HF} / \mathrm{HNO}_{3} / \mathrm{H}_{2} \mathrm{SO}_{4}$ solution performed equivalent to or better than those by the other acid solutions.

\section{Conclusion}

The conversion efficiency of mc-Si solar cells textured with the $\mathrm{HF} / \mathrm{HNO}_{3} / \mathrm{H}_{2} \mathrm{SO}_{4}$ solution $\left(\mathrm{HF}: \mathrm{HNO}_{3}: \mathrm{H}_{2} \mathrm{SO}_{4}=\right.$ $1: 1.6: 8.2)$ has relatively high values. In our study, sufficient light confinement is achieved, which contributes to the improvement of both the short circuit current and the conversion efficiency of the acid textured cells. Moreover, it takes only 30 seconds to obtain sufficiently textured surfaces. The $\mathrm{H}_{2} \mathrm{SO}_{4}$ content in the solution likely maintains textured structures during etching. Sufficient acid texturing properties with fast texturing time are adequately beneficial for the mass production of high efficiency and low cost mc-Si solar cells.

\section{Conflict of Interests}

The authors declare that there is no conflict of interests regarding the publication of this paper.

\section{Acknowledgments}

The authors gratefully thank Y. Eguchi, S. Endo, and Y. Oga of Seikei University for their various experimental supports. They also thank S. Sakamoto, Y. Ejiri, and T. Saito of Nippon Kasei Chemical Co., Ltd., for their fruitful discussions and large amounts of support.

\section{References}

[1] US Department of Energy, "2010 solar technologies market report," 2011.

[2] E. Yablonovitch, "Statistical ray Optics," Journal of the Optical Society of America, vol. 72, p. 899, 1982.

[3] H. W. Deckman, C. B. Roxlo, and E. Yablonovitch, "Maximum statistical increase of optical absorption in textured semiconductor films," Optics Letters, vol. 8, p. 491, 1983.

[4] G. Willeke, H. Nussbaumer, H. Bender, and E. Bucher, "A simple and effective light trapping technique for polycrystalline silicon solar cells," Solar Energy Materials and Solar Cells, vol. 26, no. 4, pp. 345-356, 1992. 
[5] G. Hahn, C. Zechner, M. Rinio, P. Fath, G. Willeke, and E. Bucher, "Enhanced carrier collection observed in mechanically structured silicon with small diffusion length," Journal of Applied Physics, vol. 86, no. 12, pp. 7179-7182, 1999.

[6] M. Abbott and J. Cotter, "Optical and electrical properties of laser texturing for high-efficiency solar cells," Progress in Photovoltaics, vol. 14, no. 3, pp. 225-235, 2006.

[7] Y. Inomata, K. Fukui, and K. Shirasawa, "Surface texturing of large area multicrystalline silicon solar cells using reactive ion etching method," Solar Energy Materials and Solar Cells, vol. 48, no. 1-4, pp. 237-242, 1997.

[8] Y. Nishimoto, T. Ishihara, and K. Namba, "Investigation of acid texturization for multicrystalline Silicon solar cells," Journal of the Electrochemical Society, vol. 146, no. 2, pp. 457-461, 1999.

[9] K. Kim, S. K. Dhungel, S. Jung, D. Mangalaraj, and J. Yi, "Texturing of large area multi-crystalline silicon wafers through different chemical approaches for solar cell fabrication," Solar Energy Materials and Solar Cells, vol. 92, no. 8, pp. 960-968, 2008.

[10] U. Gangopadhyay, S. K. Dhungel, P. K. Basu, S. K. Dutta, H. Saha, and J. Yi, "Comparative study of different approaches of multicrystalline silicon texturing for solar cell fabrication," Solar Energy Materials and Solar Cells, vol. 91, no. 4, pp. 285-289, 2007.

[11] D. H. Macdonald, A. Cuevas, M. J. Kerr et al., "Texturing industrial multicrystalline silicon solar cells," Solar Energy, vol. 76, no. 1-3, pp. 277-283, 2004.

[12] E. S. Marstein, H. J. Solheim, D. N. Wright, and A. Holt, "Acidic texturing of multicrystalline silicon wafers," in Proceedings of the 31st IEEE Photovoltaic Specialists Conference (PVSC '05), pp. 1309-1312, January 2005.

[13] M. Lippold, S. Patzig-Klein, and E. Kroke, "Fundamental studies of acidic wet chemical etching processes: acidification of $\mathrm{HF}-\mathrm{HNO}_{3}-\mathrm{H}_{2} \mathrm{O}$ etching mixtures," in Proceedings of the 24th EU PVSEC, vol. 1751, 2009.

[14] M. Lippold and E. Kroke, "HF- $\mathrm{HNO}_{3}-\mathrm{H}_{2} \mathrm{SO}_{4}$-mixtures for etching multicrystalline silicon wafers: etching rates, bath analytics and surface texture," in Proceedings of the 26th EU PVSEC, vol. 1800, 2011.

[15] M. Lippold, C. Gondek, and E. Kroke, "Acidic wet chemical etching of silicon surfaces-from mechanistic concepts to process optimization," in Proceedings of the 27th EU PVSEC, vol. $1877,2012$.

[16] H. Kohata and Y. Saito, "Maskless texturization of phosphorusdiffused layers for crystalline Si solar cells by plasmaless dry etching with chlorine trifluoride gas," Solar Energy Materials and Solar Cells, vol. 94, no. 12, pp. 2124-2128, 2010. 

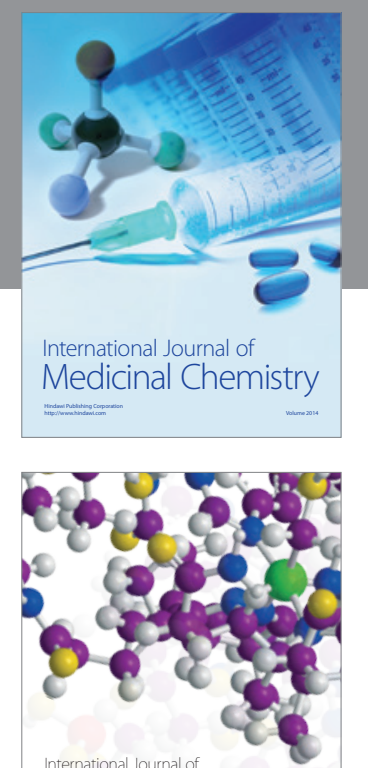

\section{Carbohydrate} Chemistry

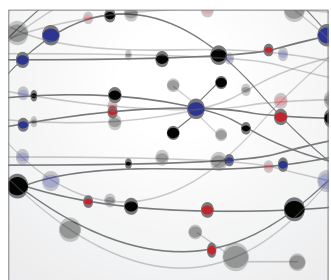

The Scientific World Journal
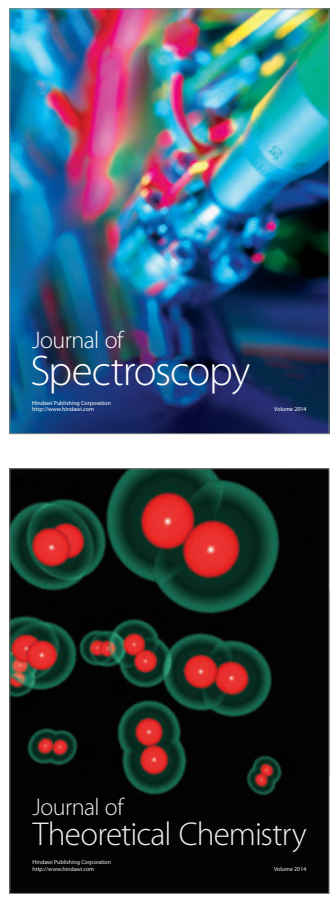
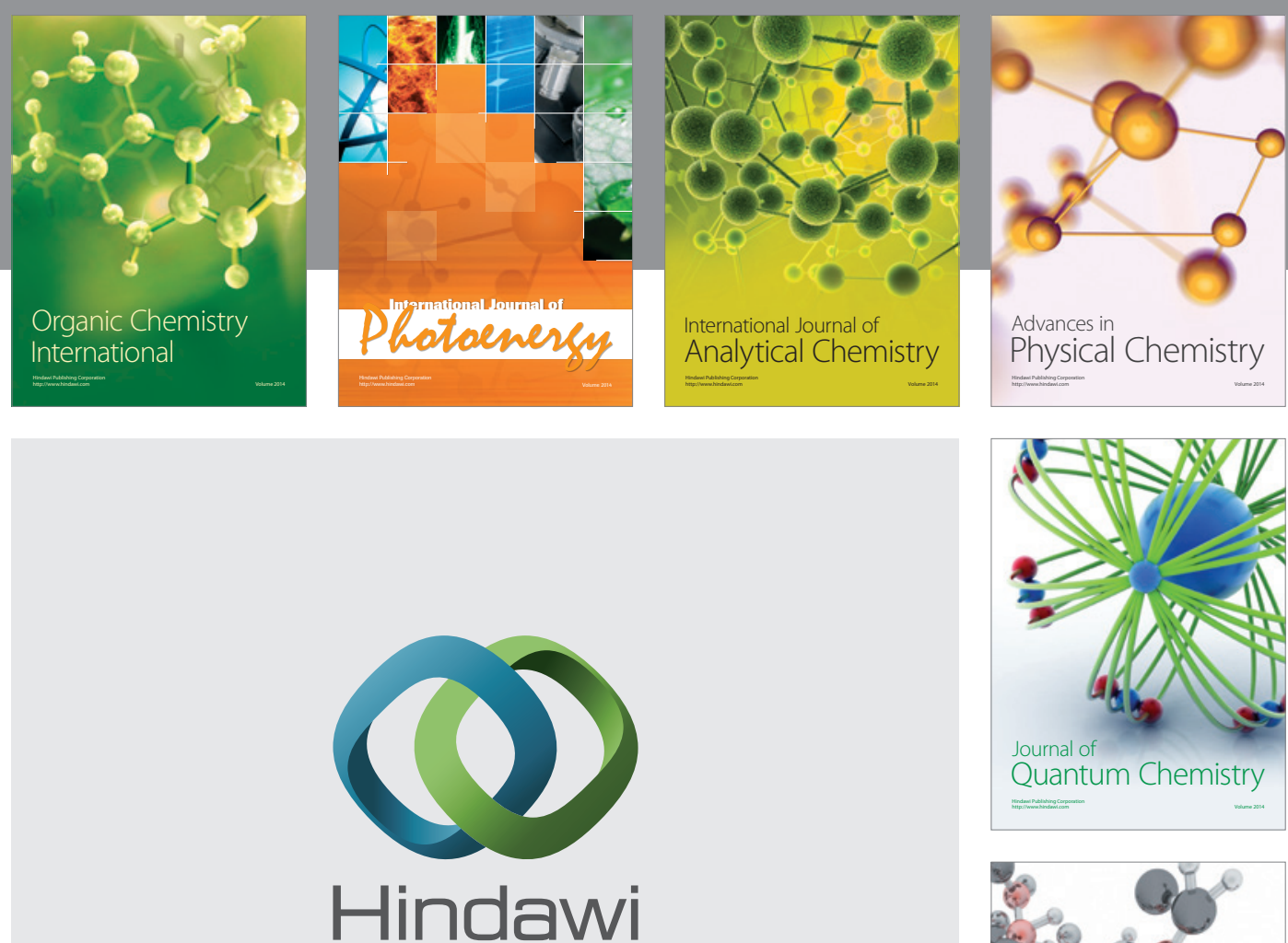

Submit your manuscripts at

http://www.hindawi.com

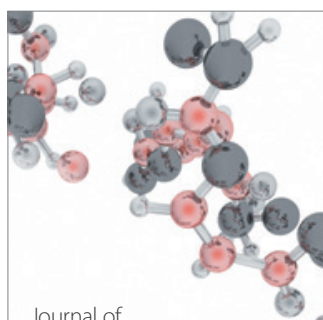

Analytical Methods

in Chemistry

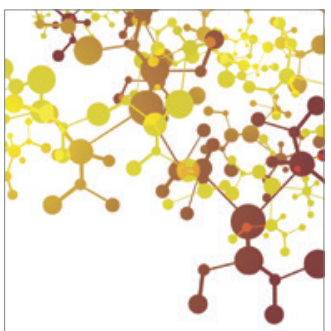

Journal of

Applied Chemistry

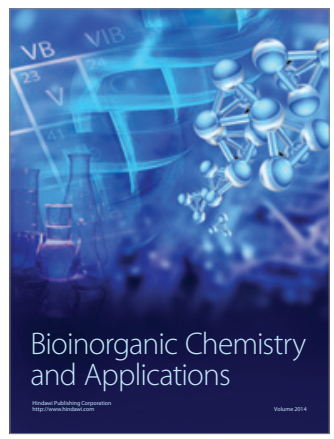

Inorganic Chemistry
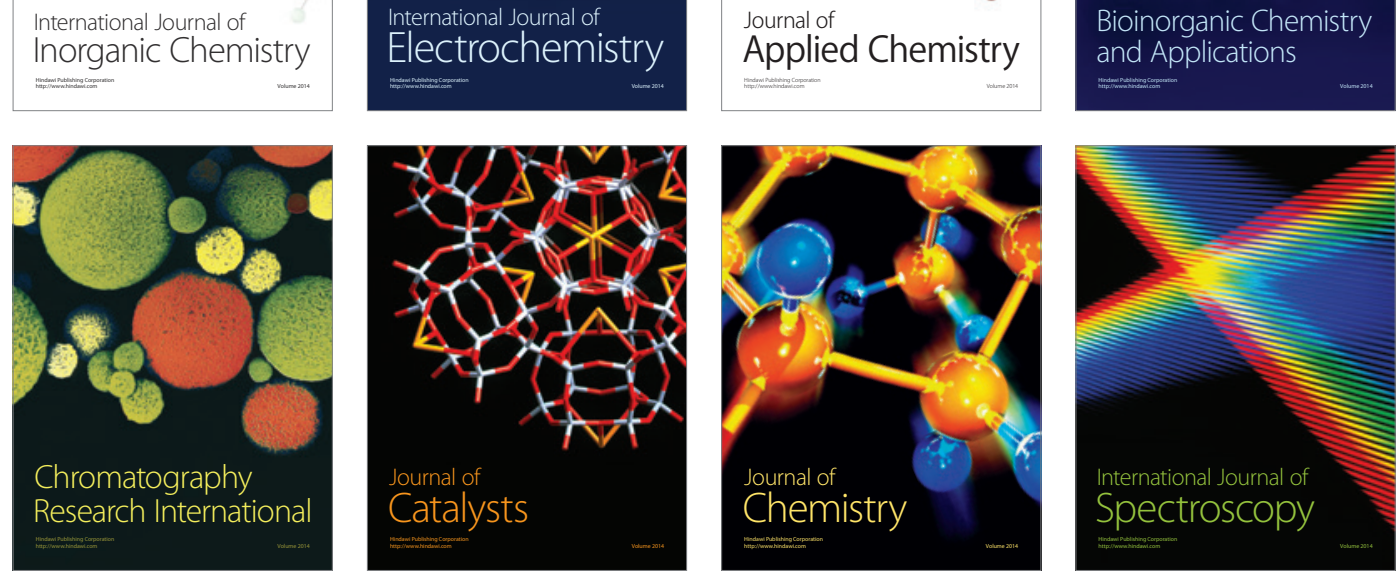